\title{
Biochemical Properties of Whole and Degermed Maize Flours during Storage
}

\author{
Dattatre ya M. Kadam*, P. Barnwal, Sonia Chadha, K. K. Singh \\ Food Grains and Oilseeds Processing Division,Central Institute of Post-Harvest Engineering and Technology (CIPHET),P.O.: PAU, Lud- \\ hiana-141004, Punjab, India
}

\begin{abstract}
An attempt was made to study the effect of packaging materials and storage periods on biochemical qualities of whole and degermed maize flours. The flours were packed in three packaging materials viz. aluminium laminated foil (ALF), high density polyethylene (HDPE) and low density polyethylene (LDPE) and its biochemical qualities were determined at ten days storage interval for 70 days storage. It was found that degermed maize flour is better in terms of mo isture, protein, fat, FFA, total acidity, ash and textural properties as compared to the whole maize flour. The mo is ture, fat and FFA were increased whereas protein, total acid and ash contents decreased with increase in storage interval. Maize flour stored in alu min ium foil found best followed by HDPE. Biochemicalqualities of degermed maize flour showed that it can be stored for longer period as compared to whole maize flour.
\end{abstract}

Keywords Whole Maize Flour, Degermed Maize Flour, Biochemical Qualities, Textural Properties

\section{Introduction}

Maize or corn (Zea mays Linn.) is one of the most versatile cereal crops of the world. It is an important cereal crop, serving as staple food to large population of A frica, Asia and North and South America. It can be processed into different breakfast items, food and feed ingredients and beverages for its consumption throughout the world (Chakraverty, 1988; Rajoo, 1998). Many people throughout the world, particularly living in Asia or people of Asiatic origin, make their own dough-based products on a daily basis. There are five general classes of corn e.g. flint corn, popcorn, flour corn, dent corn, and sweet corn (Watson, 1987a). Different types of corn have different proportions of horny and floury endosperm. The floury endosperm is softer and easier to break than the horny endosperm (Jamin \& Flores, 1998). Different parts of corn have different physical and chemical properties. Yellow corn has a horny endosperm and more carotenoids (74-86\%), which are the source of yellow color in corn (Watson, 1987b). Hardness and breakage susceptibility are related properties that can affect the utilization of corn (Pomeranzet al., 1984).

Maize germ constitutes $5-14 \%$ of the weight of kernel and is a good source of key nutrients especially $18-41 \%$ of oil (Johnston et al.,2005; MPOC, 2008). Edible oils are vital, serving as important ingredient of many foods by imparting characteristic flavor and texture to finished food products

\footnotetext{
* Corresponding author:

kadam1k@yahoo.com (Dattatreya M. Kadam)

Published online at http://journal.sapub.org/ajb

Copyright (C) 2012 Scientific \& Academic Publishing. All Rights Reserved
}

(Rudan-Tasic \& Klofutar, 1999). Chemical and physical properties of edible oils are imperative as they tie up with processing functionality, storage stability and nutritional behavior. In India, maize has become the third important food grain after wheat and rice. About $35 \%$ of the harvested corn is used as a direct food, usually in the form of unleavened bread (chapattis) though consumption in other forms (maize-on the-cob, as maize kernels) has also increased (Sandhu et al., 2007).Chapatti is most often in the form of round substantially flat pieces of dough, which are appropriately cooked/ baked. Chapatti is the staple diet of a majority of people living in the Indian subcontinent. Corn flour is used to make chapattis, which are eaten commonly in most part of India. By and large, corn breads are more commonly consumed by the less affluent people (Mehta \& Dais, 1999). Sinha and Sharada (1992) compared the chapatti-making properties of corn flours, before and after alkali treatment, and reported that untreated chapattis were more acceptable than treated ones. The desired quality parameters in chapatti are greater pliability, soft texture, light creamish brown colour, slight chewiness and baked aroma, which is usually prepared from flour (Rao et al., 1986). In many instances it is a sign of good housewife that all the dough products that she makes are of precisely the same diameter and uniform thickness, having perfect circularity and taste. This, of course, involves a considerable amount of skill, and also occupies a considerable amount of time, since it is difficult to roll a perfectly circu lar dough element from a portion of dough. The taste of chapatti depends on the quality of flour used.

The present work was carried out to study the bio-chemical qualities of whole and degermed maize flours 
stored in three packaging materials viz. aluminium laminated foil (ALF), high density polyethylene (HDPE) and low density polyethylene (LDPE) during storage.

\section{Material and Methods}

A bold variety of Maize (var. Jai Kisan), commonly grown in Karnataka state of India, was procured from the local market of Ludhiana, India for the present study. The maize kernels were cleaned by using pedal cum power operated grain cleaner (top sieve: $8.0 \mathrm{~mm} \Phi$; bottom sieve: 2.0 $\mathrm{mm} \times 2.5 \mathrm{~mm}$ ) to remove foreign matter such as dust, dirt, chaff, immature and broken grains. The experiments on different bio-chemical qualities of whole and degermed maize flours were conducted at Central Institute of Post-Harvest Engineering and Technology, Ludhiana (India).

\subsection{Sample Preparation}

Maize procured from local market was divided into two parts. The first part of whole maize was ground to make powder using burr mill whereas second part of maize was processed through CIPHET maize degermer to separate the maize grit and maize germ. Degermed maize grit was ground to make powder using burr mill and sieved for uniform particle size using ordinary household sieve. Whole maize and degermed maize flours were packed in triplicate in three packaging materials (ALF, HDPE and LDPE) for 70 days storage period with 10 days storage interval. For determination of biochemical qualities, separate packet foreach storage interval were used and discarded after each storage studies.

\subsection{Deter mination of Bio-Che mical Qualities}

\subsubsection{Mo is ture Content}

The moisture contents of the samples were determined using Kern Moisture Analyzer (Model: KERN, MLB 50-3N, Kern \& Sohn GmbH, D- 72336 Balingen, Germany).

\subsubsection{Protein}

Protein content was determined by available nitrogen in the sample by Micro Kjeldhal method (AOAC, 1980). One gram sample was digested in $20 \mathrm{ml}$ of sulphuric ac id $\left(\mathrm{H}_{2} \mathrm{SO}_{4}\right)$ at $420^{\circ} \mathrm{C}$ using copper sulphate and potassium sulphate as catalyst mixture. Digested sample was distilled using $40 \%$ $\mathrm{NaOH}$ in KjelTech (Pelican equipment Limited, Chennai, India). Ammonia was absorbed in excess of $4 \%$ boric acid solution and then titrated with standard acid $(0.1 \mathrm{~N} \mathrm{HCl})$ to estimate the protein content. The protein content was estimated using following equation:

(Sample titre - Blank titre)

$$
\mathrm{N}_{2}(\%)=\frac{\times \text { Normality of } \mathrm{HCl} \times 14 \times 100}{\text { weight of sample taken } \times 1000}
$$

and,Protein $(\%)=6.25 \times$ Nitrogen $\left(\mathrm{N}_{2}\right)$ content $(\%)$
Moisture free $5 \mathrm{~g}$ sample was taken in readymade thimble and oil was extracted in a pre-weighed beaker using petroleum ether in SOCS PLUS (Pelican Equipment Limited, Chennai, India) for 2.5 to 3 hours. The beaker was then dried in a hot air oven to evaporate petroleum ether. Final weight of the beaker was taken and used for the estimation of crude fat content of sample (AOAC, 1980). The following equation was used for estimation of crude fat content (\%) in the sample:

$$
\text { Crudefat } \%=\frac{\text { weight of fat }(\mathrm{g})}{\text { weight of sample }(\mathrm{g})} \times 100
$$

\subsubsection{Free Fatty Acids (FFA)}

The FFA was determined by using the procedure, given by Thaparet al.(1988). One gram of flour sample was added in $50 \mathrm{ml}$ of petroleum ether and stirred for 1 hour before filtering the mixture followed by 2 more washing with $5 \mathrm{ml}$ of petroleum ether. Final reaction mixture was evaporated at very low temperature. $25 \mathrm{ml}$ of ethanol and benzene (3:1) solution was added in it and $10 \mathrm{ml}$ from the above-prepared solution was taken in a separate flask and titrated against standard alkali with addition of one to two drops of $\mathrm{pH}$ indicator. The FFA (\%) was determined by using following equation:

$$
\begin{gathered}
\text { FFA }=\frac{\begin{array}{c}
\text { ml of alkali used } \times \text { Normality of alkali } \\
\times \text { molecular weight of oleic acid }
\end{array}}{\text { weight of sample }(\mathrm{g})} \\
\text { FFA }=\left(\begin{array}{c}
\begin{array}{c}
\text { volume of } \mathrm{NaOH} \times \text { Normality of } \mathrm{NaOH} \\
\times 282.46(\text { Moles of oleic acid })
\end{array} \\
\text { weight of sample or oil } \times 1000
\end{array}\right) \times 100
\end{gathered}
$$

\subsubsection{Titratable Acid ity}

Titratable acidity of reconstituted sample was estimated by diluting the aliquot of the sample with water to a fixed volume and then titrated with $0.1 \mathrm{~N} \mathrm{NaOH}$ using phenolphthalein as an indicator. Percentage acidity was calculated as the percentage of anhydrous citric acid using following formula (Kadamet al.,2010):

Total acid $(\%)=$

Titre $\times$ Normality of al kali $\times$ Volume made up $\times$ Equival ent weight of acid $\times 100$

Volume of sample taken for estimation $\times$ weight or volume of sample taken $\times 1000$

\subsubsection{Ash}

Samples $(5 \mathrm{~g})$ are taken in triplicate in crucibles. These were burnt on hot plate and then placed in an electric muffle furnace at $600^{\circ} \mathrm{C}$ for 6 hours. After cooling the crucibles to room temperature, the residue left (ash) in the crucible was weighed (AOAC, 1980). The following formula was used to calculate the ash (\%):

$$
\text { Ash } \%=\frac{\text { weight of ash }(\mathrm{g})}{\text { weight of sample }(\mathrm{g})} \times 100
$$

\subsection{Textural Properties}

\subsubsection{Crude Fat}


Based on preliminary experiments, optimized known quantity of maize flour was mixed with known quantity of water i.e. 50: $20 \mathrm{w} / \mathrm{w}$ (maize flour: water) and kneading was done manually in triplicate. Textural profile analys is (TPA) of maize flour dough balls were carried out using texture analyzer (TA-Hdi, Stable Micro system, UK). The cutting probe Blade with knife (HDP/BSK) with test speed of $1.00 \mathrm{~mm} / \mathrm{s}$, distance of $20.0 \mathrm{~mm}$ and trigger force of $0.10 \mathrm{~N}$ was used and puncture probes $\mathrm{P} 2 \mathrm{~N}$ needle was operated at test speed of $1.00 \mathrm{~mm} / \mathrm{s}$, d is tance of $10.0 \mathrm{~mm}$ and trigger force of $0.10 \mathrm{~N}$ for the textural properties of the whole and degermed maize flour dough balls. The textural behavior such as cutting force, distance, time, area and stickiness were determined for both whole and degermed maize flour dough balls.

\subsection{Statistical Analysis}

The experiments were carried out in triplicate for all the parameters at each storage interval throughout the storage period of 70 days. Data were analy zed as per one/ two factor analys is of variance (ANOVA) using LSD of AgRes statistical software package.

\section{Results and Discussions}

\subsection{Moisture Content}

Moisture content of flour is very important for its shelf life, lower the flour mo is ture, the better its storage stability (Butt et al.,2004). The storage days and packaging material are highly significant at $\mathrm{P}<0.05$. It was found that moisture content in stored product increased with increasing storage period. Minimum mo is ture was up to 30 days and then it has shown increasing trend. Hruškova and Machova (2002) observed that the changes in the moisture contents depended on the short time storage conditions and had a different time course in the individual locations. ALF packed degermed maize flour was found best with less moisture as compared to the whole maize flour. Butt et al. (2004) also reported that the mo is ture content was affected significantly due to storage, treatments, packaging and their interaction.

\subsection{Protein}

The protein content in both degermed maize and whole maize flours were decreased with increased in storage interval and significant difference was observed at $\mathrm{P}<0.05$. These are in accordance with Butt et al. (2004) who reported that the crude protein content showed a decreasing trend with storage of wheat flour. The Mean Comparison by LSD (Descending order) shows that maximum protein was retained in whole maize flour packed in ALF and HDPE. It may be due to the presence of germ in the flour which might have contributed in total quantity (Siddiqet al., 2009). The mean protein content in degermed and whole maize flour ranged from 7.22 to $8.28 \%$ and 7.86 to $8.54 \%$, respectively. From Table 1, it's clear that storage days and packaging material are highly significant at $\mathrm{P}<0.05$ and interaction between storage period and packaging materials are highly significant. The maximum protein content was found during initial storage period in aluminium foil followed by HDPE.

Table 1. Analysis of variance for protein content of whole and degermed maize flours during storage.

\begin{tabular}{cccccc}
\hline Source & df & SS & MS & F & PROB \\
\hline TOT & 143 & 88.03 & 0.6156 & 255.6577 & \\
Trt & 47 & 87.80 & 1.8681 & 775.8095 & 0.298 \\
Err & 96 & 0.23 & 0.0024 & 1.0000 & NS \\
d & 7 & 11.94 & 1.7057 & 708.3892 & 0.000 \\
& & & & & $* *$ \\
p & 5 & 30.78 & 6.1562 & 2556.5752 & 0.000 \\
& & & & & $* *$ \\
dp & 35 & 45.08 & 1.2880 & 534.8985 & 0.000 \\
Err & 96 & 0.23 & 0.0024 & 1.0000 & \\
\hline & SED & CD(0.05) & CD $(0.01)$ & & \\
d & 0.0163 & 0.0324 & 0.0429 & & \\
p & 0.0141 & 0.0281 & 0.0372 & & \\
dp & 0.0400 & 0.0795 & 0.1053 & & \\
CV & $0.61 \%$ & & & & \\
\hline
\end{tabular}

\subsection{Fat}

The fat content in both degermed maize and whole maize flours were increased with increase in storage interval. The Mean Comparison by LSD (Descending order) shows that minimum fat content was in degermed maize flour packed in ALF and LDPE. It may be due to the removal of germ from maize prior to flour making. The main component responsible for fat in maize is germ, which is responsible for fat content in it. It's clear that storage days and packaging material are highly significant at $\mathrm{P}<0.05$ and interaction between storage period and packaging materials are highly significant (Table 2). The maximum fat content was found in whole maize flour, which was not desirable from storage point of view.

\subsection{FFA}

The FFA content in both degermed maize and whole maize flours were increased with increase in storage interval as expected (Table 3). The Mean Comparison by LSD (Ascending order) shows that minimum FFA was present in degermed maize flour packed in ALF and HDPE. It may be due the separation of germ from maize prior to making flour. The main component in maize is germ, which is responsible for fat and FFA content in it. Higher lipolytic and proteolytic activities lead to loss in nutrients (protein and fat) and production of more FFA resulting in inferior sensory characteristics (Butt et al., 2004). The minimumFFA was observed in degermed maize flour packed in ALF, which is a determinant factor for safe storage and consumption.

\subsection{Total Acid}

The total acid percent content decreased with increase in storage interval for both degermed maize and whole maize 
flours. It is also reported that the acidity of commercial wheat flour was significantly increased with time regard less of the storage locations (Hruškova \& Machova, 2002). The Mean Comparison by LSD (Descending order) shows that whole maize flour had maximum total acid percentage as compared to the degermed maize flour. From Table 4, it is clear that the treatments are non significant but the packaging material and storage days and its interactions are highly significant at $\mathrm{P}<0.05$ and $\mathrm{CV}$ is $9.09 \%$.

Table 2. Analysis of variance for fat content of whole and degermed maize flours during storage.

\begin{tabular}{|c|c|c|c|c|c|}
\hline Source & df & SS & MS & $\mathrm{F}$ & PROB \\
\hline TOT & 143 & 280.57 & 1.9620 & 601.13 & \multirow{3}{*}{$\begin{array}{c}0.813 \\
\text { NS }\end{array}$} \\
\hline Trt & 47 & 280.25 & 5.9629 & 1826.94 & \\
\hline Err & 96 & 0.31 & 0.0032 & 1.00 & \\
\hline $\mathrm{d}$ & 7 & 46.11 & 6.5884 & 2018.60 & $\begin{array}{c}0.000 \\
* *\end{array}$ \\
\hline $\mathrm{p}$ & 5 & 217.41 & 43.4824 & 13322.27 & $\begin{array}{c}0.000 \\
* *\end{array}$ \\
\hline $\mathrm{dp}$ & 35 & 16.72 & 0.4779 & 146.43 & $\begin{array}{c}0.000 \\
* *\end{array}$ \\
\hline \multirow[t]{2}{*}{ Err } & 96 & 0.31 & 0.0032 & 1.00 & \\
\hline & SED & $\mathrm{CD}(0.05)$ & $\mathrm{CD}(0.01)$ & & \\
\hline d & 0.0190 & 0.0378 & 0.0500 & & \\
\hline $\mathrm{p}$ & 0.0164 & 0.0327 & 0.0433 & & \\
\hline $\mathrm{dp}$ & 0.0466 & 0.0925 & 0.1225 & & \\
\hline $\mathrm{CV}$ & $1.64 \%$ & & & & \\
\hline
\end{tabular}

Table 3. Analysis of variance for FFA of whole and degermed maize flours during storage.

\begin{tabular}{ccccrc}
\hline Source & df & SS & MS & F & PROB \\
\hline TOT & 143 & 92.33 & 0.6456 & 1852.19 & \\
Trt & 47 & 92.30 & 1.9638 & 5633.35 & 0.434 \\
Err & 96 & 0.03 & 0.0003 & 1.00 & NS \\
d & 7 & 57.95 & 8.2793 & 23749.54 & 0.000 \\
$* *$ \\
$\mathrm{p}$ & 5 & 25.57 & 5.1148 & 14672.19 & 0.000 \\
$* *$ \\
$\mathrm{dp}$ & 35 & 8.77 & 0.2506 & 718.85 & 0.000 \\
Err & 96 & 0.03 & 0.0003 & 1.00 & \\
\hline & $\mathrm{SED}$ & $\mathrm{CD}(0.05)$ & $\mathrm{CD}(0.01)$ & & \\
$\mathrm{d}$ & 0.0062 & 0.0123 & 0.0163 & & \\
$\mathrm{p}$ & 0.0053 & 0.0107 & 0.0141 & & \\
$\mathrm{dp}$ & 0.0152 & 0.0302 & 0.0400 & & \\
CV & $1.63 \%$ & & & & \\
\hline
\end{tabular}

\subsection{Ash}

The ash content decreased with increase in storage interval for both degermed maize and whole maize flours, as expected. The Mean comparison by LSD (Ascending order) shows that the presence of ash content was less in all the samples during 70days of storage period. Ash content increase was very less in degermed maize flour as compare to the whole maize flourpacked irrespective of packagingmaterial used. From Table 5, it's clear that storage days and packaging material are highly significant at $\mathrm{P}<0.05$ and interaction between storage period and packaging materials are highly significant. The minimum ash content was found in all packaging materials stored up to 70 days of interval.

Table 4. Analysis of variance for total acid (\%) of whole and degermed maize flours during st orage.

\begin{tabular}{ccccrc}
\hline Source & $\mathrm{df}$ & $\mathrm{SS}$ & $\mathrm{MS}$ & $\mathrm{F}$ & PROB \\
\hline TOT & 143 & 1.74 & 0.0122 & 67.78 & \\
Trt & 47 & 1.73 & 0.0368 & 204.18 & 0.260 \\
Err & 96 & 0.01 & 0.0001 & 1.00 & $\mathrm{NS}$ \\
$\mathrm{d}$ & 7 & 1.41 & 0.2014 & 1117.22 & 0.000 \\
$* *$ \\
$\mathrm{p}$ & 5 & 0.16 & 0.0337 & 187.22 & 0.000 \\
$* *$ \\
$\mathrm{dp}$ & 35 & 0.15 & 0.0043 & 24.00 & 0.000 \\
Err & 96 & 0.01 & 0.0001 & 1.00 & \\
\hline & SED & $\mathrm{CD}(0.05)$ & $\mathrm{CD}(0.01)$ & & \\
$\mathrm{d}$ & 0.0044 & 0.0088 & 0.0117 & & \\
$\mathrm{p}$ & 0.0038 & 0.0076 & 0.0101 & & \\
$\mathrm{dp}$ & 0.0109 & 0.0217 & 0.0288 & & \\
CV & $9.09 \%$ & & & & \\
\hline
\end{tabular}

Table 5. Analysis of variance for Ash content (\%) of whole and degermed maize flours during storage.

\begin{tabular}{ccccrc}
\hline Source & df & SS & MS & F & PROB \\
\hline TOT & 143 & 12.74 & 0.0891 & 67.24 & \\
Trt & 47 & 12.61 & 0.2684 & 202.56 & 0.247 \\
Err & 96 & 0.12 & 0.0013 & 1.00 & \\
d & 7 & 0.97 & 0.1398 & 105.55 & $0.000^{* *}$ \\
$\mathrm{p}$ & 5 & 10.27 & 2.0554 & 1551.28 & $0.000 * *$ \\
$\mathrm{dp}$ & 35 & 1.35 & 0.0388 & 29.29 & $0.000 * *$ \\
Err & 96 & 0.12 & 0.0013 & 1.00 & \\
\hline & SED & $\mathrm{CD}(0.05)$ & $\mathrm{CD}(0.01)$ & & \\
$\mathrm{d}$ & 0.0121 & 0.0240 & 0.0318 & & \\
$\mathrm{p}$ & 0.0105 & 0.0208 & 0.0276 & & \\
$\mathrm{dp}$ & 0.0297 & 0.0590 & 0.0781 & & \\
$\mathrm{CV}$ & $3.51 \%$ & & & & \\
\hline
\end{tabular}

\subsection{Textural Properties of Whole and Deger med Maize Flour Dough}

The ANOVA of textural properties of the whole and degermed maize flour dough balls are presented in Tables 6 and 7 , respectively. The Mean Comparison by LSD (Descending order) shows that the textural properties of the dough increased with increasing storage period and highly significant at $\mathrm{P}<0.05$ (Tables $6 \&$ 7). Siddiq et al. (2009) reported that textural properties (hardness and stickiness) of wheat flour blends with defatted maize germ flour (DMGF) increased with storage and the increase in stickiness is probably due to the low oil content of DMGF, and due to increased inter-particle friction. Rehydration time of 10 to 20 minute 
gave the best dough for cutting property, which is more suitable for making chapatti. The better results were observed for 40 days storage and 20 minutes rehydration time. The CV value is less in degermed maize flour dough as compared to the whole maize flour dough. The comparison between storage days and rehydration time is significant for degermed maize dough and other interaction shown non-significant.

Table 6. Analysis of variance for text ural propert ies of whole maize flour dough during storage.

\begin{tabular}{|c|c|c|c|c|c|}
\hline Source & $\mathrm{df}$ & SS & MS & F & PROB \\
\hline TOT & 349 & 3411.44 & 9.7749 & 5.1559 & \\
\hline Trt & 174 & 3079.66 & 17.6992 & 9.3356 & $\begin{array}{c}0.000 \\
* *\end{array}$ \\
\hline Err & 175 & 331.78 & 1.8958 & 1.0000 & \\
\hline $\mathrm{d}$ & 6 & 1765.86 & 294.3110 & 155.2366 & $\begin{array}{c}0.000 \\
* *\end{array}$ \\
\hline $\mathrm{t}$ & 4 & 56.41 & 14.1026 & 7.4385 & $\begin{array}{c}0.000 \\
* *\end{array}$ \\
\hline $\mathrm{c}$ & 4 & 25.79 & 6.4487 & 3.4015 & $\begin{array}{c}0.010 \\
* *\end{array}$ \\
\hline $\mathrm{dt}$ & 24 & 1016.94 & 42.3726 & 22.3498 & $\begin{array}{c}0.000 \\
* *\end{array}$ \\
\hline tc & 16 & 21.23 & 1.3272 & 0.7001 & $\begin{array}{c}0.792 \\
\text { NS }\end{array}$ \\
\hline $\mathrm{dc}$ & 24 & 37.64 & 1.5684 & 0.8273 & $\begin{array}{c}0.699 \\
\mathrm{NS}\end{array}$ \\
\hline $\mathrm{dtc}$ & 96 & 155.76 & 1.6225 & 0.8558 & $\begin{array}{c}0.800 \\
\text { NS }\end{array}$ \\
\hline \multirow[t]{2}{*}{ Err } & 175 & 331.78 & 1.8958 & 1.0000 & \\
\hline & SED & $\mathrm{CD}(0.05)$ & $\mathrm{CD}(0.01)$ & & \\
\hline $\mathrm{d}$ & 0.2753 & 0.5435 & 0.7171 & & \\
\hline $\mathrm{t}$ & 0.2327 & 0.4593 & 0.6061 & & \\
\hline $\mathrm{c}$ & 0.2327 & 0.4593 & 0.6061 & & \\
\hline $\mathrm{dt}$ & 0.6157 & 1.2153 & 1.6036 & & \\
\hline tc & 0.5204 & 1.0271 & 1.3553 & & \\
\hline $\mathrm{dc}$ & 0.6157 & 1.2153 & 1.6036 & & \\
\hline $\mathrm{dtc}$ & 1.3769 & 2.7175 & 3.5858 & & \\
\hline $\mathrm{CV}$ & $34.26 \%$ & & & & \\
\hline
\end{tabular}

\section{Conclusions}

Degermed and whole maize flours were packed in three packaging materials (LDPE, HDPE and ALF) and stored for seventy days. The various biochemical qualities viz. mo isture content, protein, fat, FFA, total acid and ash and textural properties of the flour dough were determined at storage interval of ten days. The minimum changes in biochemical qualities were found in aluminium-laminated foil during storage of both the flours (whole maize and degermed maize flours). It was also found that degermed maize flour can be safely consumed up to 60 days. The textural properties of the dough increased with increasing storage period. Rehydration time of 10 to 20 minute gave the best dough for cutting and puncture properties that are more suitable for making chapatti and storage period of 40 days was observed as the best.
Table 7. Analysis of variance for textural properties of degermed maize flour dough during storage.

\begin{tabular}{|c|c|c|c|c|c|}
\hline Source & df & SS & MS & $\mathrm{F}$ & PROB \\
\hline TOT & 349 & 2749.51 & 7.8782 & 7.0701 & \multirow{3}{*}{$\begin{array}{c}0.000 \\
* *\end{array}$} \\
\hline Trt & 174 & 2554.51 & 14.6811 & 13.1751 & \\
\hline Err & 175 & 195.00 & 1.1143 & 1.0000 & \\
\hline d & 6 & 1548.67 & 258.1121 & 231.6344 & $\begin{array}{c}0.000 \\
* *\end{array}$ \\
\hline $\mathrm{t}$ & 4 & 90.28 & 22.5708 & 20.2555 & $\begin{array}{c}0.000 \\
* *\end{array}$ \\
\hline $\mathrm{c}$ & 4 & 1.44 & 0.3620 & 0.3249 & $\begin{array}{c}0.861 \\
\text { NS }\end{array}$ \\
\hline $\mathrm{dt}$ & 24 & 790.77 & 32.9490 & 29.5691 & $\begin{array}{c}0.000 \\
* *\end{array}$ \\
\hline tc & 16 & 7.45 & 0.4657 & 0.4180 & $\begin{array}{c}0.977 \\
\text { NS }\end{array}$ \\
\hline $\mathrm{dc}$ & 24 & 20.33 & 0.8473 & 0.7605 & $\begin{array}{c}0.782 \\
\text { NS }\end{array}$ \\
\hline $\mathrm{dtc}$ & 96 & 95.54 & 0.9952 & 0.8931 & $\begin{array}{c}0.728 \\
\text { NS }\end{array}$ \\
\hline \multirow[t]{2}{*}{ Err } & 175 & 195.00 & 1.1143 & 1.0000 & \\
\hline & SED & $\mathrm{CD}(0.05)$ & $\mathrm{CD}(0.01)$ & & \\
\hline d & 0.2111 & 0.4166 & 0.5498 & & \\
\hline $\mathrm{t}$ & 0.1784 & 0.3521 & 0.4646 & & \\
\hline $\mathrm{c}$ & 0.1784 & 0.3521 & 0.4646 & & \\
\hline $\mathrm{dt}$ & 0.4720 & 0.9317 & 1.2294 & & \\
\hline tc & 0.3989 & 0.7874 & 1.0390 & & \\
\hline $\mathrm{dc}$ & 0.4720 & 0.9317 & 1.2294 & & \\
\hline $\mathrm{dtc}$ & 1.0556 & 2.0833 & 2.7490 & & \\
\hline $\mathrm{CV}$ & $27.07 \%$ & & & & \\
\hline
\end{tabular}

\section{REFERENCES}

[1] AOAC (1980). Official Methods of Analysis, 11th edn. Washington,DC: Association of official analytical chemists

[2] Butt,M.S., Nasir, M., Akhtar, S. \& Sharif, K. (2004). Effect of moisture and packaging on the shelf life of wheat flour. Journal of Food Safety, 5, 1-6

[3] Chakraverty, A. (1988). Post harvest technology of cereals, pulses and oilseeds. India: Oxford \& IBH publication (p. 177)

[4] Hruškova, M. \& Machova, D. (2002). Changes of wheat flour properties during short term storage. Czech Journal of Food Science, 20, 125-130

[5] Jamin, F. F. \& Flores, R. A. (1998). Effect of additional separation and grinding on the chemical and physical properties of selected corn dry milled streams. Cereal Chemistry, $75,166-170$

[6] Johnston, D. B., McAloon, A. J., Moreau, R. A., Hicks, K. B. \& Singh, V. (2005). Composition and economic comparison of germ fractions derived from modified corn processing technologies. Journal of the American Oil Chemists' Society, $82,603-608$

[7] Kadam, D. M., Wilson, R. A. \& Kaur, S. (2010). Determination of biochemical properties of foam mat dried mango powder. International Journal of Food Science and Technology, 45 (8), 1626-1632 
[8] Mehta, D. C. \& Dais, F. F. (1999). Maize: perspectives and applications in India. Starch/Starke, 51, 52-57

[9] MPOC (Malay sian Palm Oil Council) (2008). Global Oils and Fats. Business Magazine, 5, 33-34

[10] Pomeranz, Y., Martin, C. R., Traylor, D. D. \& Lai, F. S. (1984). Corn hardness determination. Cereal Chemistry, 61, 147

[11] Rajoo, R. K. (1998). Maize: The Golden Grain of Himachal Pradesh. Kaly ani Publishers, Ludhiana, India

[12] Rao, H. P., Leelavathi, K. \& Shurpalekar, S. R. (1986). Test baking of chapatti -Development of a method. Cereal chemistry, 63, 297-303

[13] Rudan-Tasic, D. \& Klofutar, C. (1999). Characteristics of vegetable oils of some Slovene manufacturers. Acta Chimica Slovenica, 46, 511-521

[14] Sandhu, K. S., Singh, N. \& Malhi, N. S. (2007). Some properties of corn grain and their flours I: phy sicochemical, functional and chapatti-making properties of flours. Food Chemistry, 101, 938-946
[15] Siddiq, M., Nasir, M., Ravi, R., Dolan, K. D. \& Butt, M. S. (2009). Effect of defatted maize germ addition on the functional and textural properties of wheat flour. International Journal of Food Properties, 12(4), 860-870

[16] Sinha, R. \& Sharada, D. (1992). Chemical characteristics of maize grains and their relationship to roti quality. Journal of Food Science and Technology, 4, 243-245

[17] Thapar, V. K., Sehgal, V. K. \& Paul, S. (1988). Post harvest quality analysis of food grains - research bulletin. Department of Processing and Agricultural Structures, Punjab Agricultural University, Ludhiana, p 13-32

[18] Watson, A. S. (1987a). Structure and composition. In: Watson S.A., Ramstad, P.E. (Eds.), Corn chemistry and technology. St. Paul, MN: American Association of Cereal Chemists, pp. 53-82

[19] Watson, A. S. (1987b). Measurement and maintenance of quality. In: Watson S.A., Ramstad, P.E. (Eds.), Corn chemistry and technology. St. Paul, MN: American Association of Cereal Chemists, pp. 133 